\title{
The Relation Between Institutional Ownerships, Debt Policy, Dividend Policy and Company Performance in Terms of Clarifying Agency Conflict Mechanism : Case Study at Manufacturing Companies Listed at the Indonesian Stock Exchange
}

\author{
Mateus Xavier Da Costa Cabral, Arsono Laksamana, Mudjilah Rahayu \\ PhD Student in Doctoral Program Widya Mandala Catholic University Surabaya \\ Prof. of Faculty of Business, Widya Mandala Catholic University Surabaya \\ Catholic University Surabaya
}

\begin{abstract}
Companies that go public, in general, have been managed professionally that can be tailored to the consumers' needs under applicable regulations. Management within a company's business entity involves an agency relationship. The purpose of this study is to examine: a) a reciprocal relationship between institutional ownership, debt policy, dividend policy and company performance of manufacturing companies of the Indonesian Stock Exchange, b) the influence of institutional ownership, debt policy, dividend policy on the company performance of the manufacturing companies of the Indonesian Stock Exchanage.

This type of research includes associative research with a quantitative approach. The samples of this research as many as 98 manufacturing companies listed at the Indonesian Stock Exchange of the period of 2006-2015 with the technique of determining purposive samplings. Data analysis technique used in this research is Granger Causality test.

The results of this study are: a) there is no reciprocal relationship between institutional ownership and debt policy, b) there is no reciprocal relationship between institutional ownership with dividend policy, c) no reciprocal relationship between debt policy and dividend policy, d) there is no reciprocal relationship between institutional ownership and company performance; e) there is no reciprocal relationship between debt policy and company performance; f) there is no reciprocal relationship between dividend policy and company performance; g) institutional ownership has a positive and partially significant influence on company performance, h) debt policy has a positive and partially significant influence on company performance, and i) dividend policy has positive and partially significant influence to companies performance on manufacturing company listed at the Indonesian Stock Exchange.
\end{abstract}

Keywords: Institutional Ownership, Debt Policy, Dividend Policy, Corporate Performance

\section{Preface}

A company in its operational activity will require a huge amount of fund to finance its investment plan. On that account a company is encountered with various kinds of financing problems. One of the financing sources is capital market. Capital market is an organized market trading in stocks and bond (debentures), utilizing the service of brokers, commissioners and underwrites (Tandelilin, 2010:7). 
Companies that have gone public, in general are professionally managed and can be adjusted to the consumers' need under applicable regulation. Management in a corporate will involve agency relationship. Agency relationship which exists, will involve relationship between the stock holders and the management, and also between the creditors and the management. This condition make possibly that agency conflicts occur between stock holders and the management.

Agency theory is a theory which is common in management field and has been a grand theory in management world Jensen and Meckling (1976) explained that agency relationship occurs when one stock holder or more (principal) hire a manager (agent) to offer a service and eventually delegate authority and decision making to that agent. Jensen and Meckling (1976) declared that a higher institutional ownership of a company would strengthen external control of the company, hence reducing agency fund. Because the higher institutional ownership of a company, the lower debt/loan used to finance the company. A high level of institutional ownership will result in a more intensive monitoring efforts which then can restrict opportunistic attitude of a manager. The higher institutional ownership, the stronger external control towards a company, thus lessening the influence of dividend policy on institutional ownership (Dewi, 20018).

Crutchley et al. (1999) stated that agency conflict control mechanism i.e dividend, debt, and institutional ownership had a mutual support in reducing agency conflict. Easterbrook (1984) stated that devidend had a positive influence towards debt, which means that dividend divided in great amount will cause higher debt. A company that divide dividend in in a great amount will require additional fund by borrowing money to finance its investment. So dividend policy had an impact towards debt policy.

Risk enhancement will cause the company to reduce divident payment but increase institutional ownership and debt. Dividend policy apply to impact managerial ownership will reduce agency cost. The research concluded that there was substitutional relationship between dividend policy and institutional ownership. This was also according to Crutchleyet al. (1999), Chen and Stainer (1999), that dividend, debt and insider ownership had a substitutional relationship, whereas according to Crutchley et al. (1999), institutional ownership could be used as a substitutional variable to control, monitor and reduce agency conflict.

\section{Theoretical Study}

\section{Institutional Ownership}

Institutional Ownership is percentage of options owned by the institution (Beiner et al, 2003). Institutional investor was a transient owner which was usually focused on current earnings (Porter, 1992). Whereas second opinion viewed institutional investors as sophisticated investors who would do the monitoring function more effectively and not easily cheated (Bushee, 1998). The perspective of sophisticated investors was also supported by research by Shillerdan Pound (1989) who stated that institutional investors spent more time for their investment analysis. This supported Bushee's 1998 opinion i.e sophisticated investors could not be easily cheated by manager manipulative behavior, because they have conducted monitoring function and analysis about their investment properly. Institutional ownership could be measured by dividing the member of stocks owned by the institution with the total stock distributed, as seen in the formula below (Imanta dan Satwiko, 2011):

$$
I N S T=\frac{\text { Institutional Stocks }}{\text { Total Stock Outstanding }}
$$

\section{Debt Policy}


Basically, debt Policy is a policy used to determine Company Performance. Company debt policy is a company management conduct in order to fund company operational activities by means of capital derived from debt. This is closely related with the capital structure determined by the company (Karina Putri, 2012).

Debt policy is usually measured with Debt Equity Ratio (DER) which reflects ratio between total long term debt and owner's equity. So it can be said that the lower the DER, the higher the debt of the company and company's capacity to pay the debt is also high. If a company is continuously indebted, its obligation to pay the debt is greater. Eventually, this will influence the net income of the company to provide and pay out dividend to stock holders. This is due to the fact that the obligation to pay the debt is given more priority than the obligation to pay out dividend to stock holders (Karina Putri, 2012). Debt policy in this research was measured by Debt to Equity Ratio and Debt to Assets Ratio, using a formula as below.

$$
D E R=\frac{\text { Total Debt }}{\text { Capital (equity) }}
$$

\section{Dividend Policy}

According to Horne and Wachowicz (1998, dividend policy was inseparable from the decision made for the company's funding. Dividend payout ratio determined the sum of retained profit as sources of funding. Dividend policy was obtained by dividend per share by Earnings per share. Eranings per share was obtained by deducting the net profit from dividend payout to the preference stock holders then divided by the number of stocks outstanding (Nuringsih, 2005). Dividend policy was closely related with the company funding decision. The ratio of dividend payout determined the amount of retained profit as sources of funding. The bigger the profit retained, the smaller the profit allocated for dividend payout. Profit retained allocation and dividend payout were two main aspects in dividend policy (Wachowicz, 1997). Dividend policy was measured using Dividend Payout Ratio (DPR) as below formula (Murhadi, 2013):

$$
D P R=\frac{\text { Dividend Per Share }}{\text { Earning Per Share }}
$$

\section{Company Performance}

Company performance is the ability of a company to manage the existing fund sources in order to give value to the company. By knowing the performance of a company, we can measure the efficiency level and productivity of the company. Moreover one performance assessment is beneficial to learn how a company develops. According to Helfert (1996) in Srimindarti (2004),company performance was a complete state view of a company within a certain period of time. Because performance was a result or achievement which was influenced by company operational activities in utilizing resources owned.

Performance measurement according to Mardiasmo (2004) aimed to help manager to assess strategy achievement by means of financial and non financial measuring instrument. Performance measuring system could be used as an instrument to control a company, because performance measurement was strengthened by determining reward and punishment system. Company performance in this research was measured via Returned on Equity (ROE), using the following formula (Syamsuddin, 2009:65):

$$
R O E=\frac{\text { Net Profit After Tax }}{\text { Stockholder Equity }}
$$




\section{The Relation Between Variables}

\section{Mutual Relation between Institutional Ownership and Debt Policy}

Agency theory explained that management interest and stock holders was often contradictory causing conflicts between them. The Manager gave priority to his personal interest, on the other hand stock holders were against this personal interest of the manager because this would result in an increase of the company expenses, hence profit decline of the company. Stock holders wanted that the expenses should be paid out by making debts, but the manager would disagree due to the fact that making debt was highly risky (Jensen danMeckling (1976) inWati (2012). Institutional investor existence was a debt substitution to reduce agency problems. This meant that the Institutional investors could control the debt policy of a company while debt was also a monitoring instrument for management because of the interest which should be borne and paid out in due date.

Jensen and Meckling (1976) stated that a higher institutional ownership would strengthen external control of a company, thus reducing agency expenses. This was because the higher company institutional ownership, the lower debt used to fund the company. Similarly with research conducted by Chen and Steiner (1999) which showed that institutional ownership and debt policy had a negative relation. A high company debt policy could increase the company risk, reckoning the obligation which should be settled was also increase so the debt policy had a negative relation with institutional ownership. When a company had a high debt, it would have a negative influence toward institutional ownership. Institution would conduct an increased performance monitoring the manager in a company with high risk. This control would lead the manager to use debt more efficiently to anticipate possible financial distress and company bankruptcy (Crutchley, et al., 1999).

Similar thought was adopted by Jensen and Meckling (1976) who stated that at the time the agency expenses and interest were high, due to debt, it would push the company to lower the debt and the company would be highly demanded by the institution. Dharmastuti et al (2003) stated that debt was one of the external sources used by a company to fund their financial requirement. A low debt will impact investors' interest. Institutional ownership and debt policy had a significant relation. Debt using level of a company could be shown among others by comparing debt ratio towards equity (DER), i.e the ratio of debt towards own capital. Debt ratio to equity (DER) was also commonly known as leverage. Putra (2008) stated that a company debt policy was inter related with the optimum capital structure. The bigger the leverage was, the bigger the assets or institutional funding, the higher the debt would be. Therefore the company could fail to payout its debt, and the institution would encounter potential risk of bankruptcy. As a consequence, stock market would react negatively which would affect the value of the company.

According to Maftukhah (2013), the institutional ownership had a positive and significant impact towards debt to Equity Ratio (DER). Institutional ownership was a percentage of company stock owned by institutional investors, such as non-governmental organization (LSM), State owned enterprises (BUMN), as well as private enterprises (McConnell \& Servaes, 1990; Bathala et al., 1994). Institutional investors would push on increase of optimum monitoring towards management performance mainly in making decision about debt. This meant that the institutional Investors who monitor agency was restricted only to monitor management behavior, and were not actively involved in decision making about debt. Positive impact meant that the higher the institutional ownership, the higher the debt, possibly due to certain reasons which enforced them to increase debt, for instance when the company planned to expand their business.

Research by Wati (2012) proved that institutional ownership variable had a negative but not significant impact on debt policy. On the contrary, debt policy variable had a negative impact which is significant on institutional ownership. 
$\mathrm{H}_{1 \mathrm{a}}$ : There was a mutual relation between institutional ownership and debt policy in manufacturing company listed at the Indonesian stock exchange.

\section{Mutual Relation between Institutional Ownership and Dividend Policy.}

According to agency theory, agency conflict occurred due to disharmony between the company owner and the manager. The owner expected the manager to work hard to maximize the owner's utility, on the other hand, the manager tend to try hard to maximize his own utility. Institution investors ownership were fund owned by several individual investors, so the investors were strongly motivated to play a role as effective monitoring agents to reduce agency problems and control opportunistic behavior of a manager. This concluded that a high institutional ownership could reduce agency cost and it would be possible that the company pay out dividend in small amount (Kartikasari and Lasmana, 2013).

Dividend, basically, is part of company's profit distributed to company owner and investors. Dividend policy, according to Brigham, et al (1999) lead o a decision whether to distribute the profit or keep it for re investment of the company. Dividend policy is a decision to determine the portion of dividend for distribution to stock holders and the portion that is retained for reinvestment. Al-Najjar and Taylor (2008) proved that there was no relation between institutional ownership and dividend policy. This indicated that the more the institutional investors were, the less the dividend to pay out. A high institutional ownership would result in supervision attempt which was more, effective hence could restrain manager opportunistic behavior. The higher the institutional ownership, the stronger the external control of the company and this would reduce the impact of dividend on institutional ownership (Dewi, 2008).

The relation between institutional ownership and dividend policy was based on research by Wati (2012), Kardianah (2013), Purwoko (2013), and Kurniawati et.al (2015) which showed that institutional ownership had a positive and significant impact on dividend policy. Wati (2012) also proved that dividend policy variable had a positive and significant impact on institutional ownership. This indicated that when institutional ownership was high, the dividend paid out by the company was also high. This result revealed that simultaneous relation between institutional ownership and dividend policy was complimentary in reducing agency conflicts. Kartinah (2011) proved that dividend policy variable had a causal positive and significant impact on institutional ownership. A high dividend policy would increase institutional ownership taking into account income stability. But Kartikasari and Lasmana (2013) proved that dividend policy gave a negative and significant impact on institutional ownership.

$\mathrm{H}_{1 \mathrm{~b}}$ : There was a mutual relation between institutional ownership and dividend policy in manufacturing companies listed at the Indonesian Stock Exchange.

\section{Mutual Relation between Debt Policy and Dividend Policy.}

Megginson (1997) stated that debt policy had a negative relation with dividend policy. A company with a high level of debt would attempt to reduce its agency cost by reducing debt, so that to fund its investment an internal cash was used instead of paying out dividend. Stock holders would let go internal cash flow to finance investment, which priorly were used for operational cost and dividend payout. This indicated that the obligation was to settle this by reducing debt and retaining dividend payout. According to Maftukhah (2013), a positive and significant relation between Dividend Pay-out Ratio (DPR) and Debt to Equity Ratio (DER) in line with Pecking Order theory, stated that company financing funding activities gave priority to retained profit, so when retained profit was big, DPR and DER would become small. A constant dividend payout would cause a constant fund required yearly so that the company fund requirement would increase. A company paying out dividend in a great amount, would 
need additional debt to finance their investment, meaning that dividend policy would give impact to debt policy accordingly.

The relation between debt policy and dividend policy was based on research result conducted by Larasati (2011) and Sheisarvian, et.al. (2015) which stated that dividend policy had a negative and significant impact on company debt policy. Research by Indana (2015) concluded that dividend policy had a positive but not significant impact on debt policy. Whereas research by Marhamah (2016) and Maftukhah (2013) showed that the dividend policy had a positive and significant impact on debt policy. Research by Wati (2012) revealed that dividend policy variable had a negative and significant impact on debt policy. On the other hand, Wati (2012), Gautama and Haryati (2014); and Thaib and Taroreh (2015) stated that debt policy variable had a negative and significant impact on dividend policy. This result indicated there was simultaneous relation between dividend and debt.

$\mathrm{H}_{1 \mathrm{c}}$ : There was a mutual relation between debt policy and dividend policy on manufacturing companies listed at the Indonesian Stock Exchange.

\section{Mutual Relation Between Institutional Ownership and Company Performance.}

Agency theory mentioned principal as stock holder while what was meant by agent was management who managed the company. In financial management, the main purpose of a company is to maximize the welfare of stock holders, therefore, management should on behalf of stock holders. In fact, sometimes agency conflict occurred between the management and the stock holders. Managerial ownership and institutional ownership were two main governance corporate mechanism, which helped control problems of agency conflicts. So, institutional investors ownership would push to increase an optimal control towards company performance (Hamidah, 2013).

Research by Crutchley et al. (1999) also showed that institutional ownership had a supervisory function to control agency conflicts so the company performance would improve. Thus, there was a positive impact of institutional ownership towards company performance. Research by AlGharaibeh et al (2013) showed there was a positive and significant impact between institutional ownership and company performance. The same result was shown by Han, Lee, and Suk (1999), in which institutional ownership had a positive impact on company performance. The higher the institutional ownership in a company, the stronger the company control would be. It was also the same with high concrete thinking to improve a company would have impact on increase of company performance. The relation between institutional ownership and company performance was also based on the result of research by Wiranata and Nugrahanti (2013) in which institutional ownership had a negative and not significant impact on profitability. While Hamidah (2013) succeeded to prove that institutional ownership gave a negative and significant impact on profitability (return on assets) of banking companies listed at the Indonesian Stock Exchange. Dharmastuti (2013) proved that percentage of institutional ownership gave positive and significant impact on financial performance.

$\mathrm{H}_{1 \mathrm{~d}}$ : There was a mutual relation between institutional ownership and company performance on manufacturing companies listed at the Indonesian Stock Exchange.

\section{Mutual Relation between Debt Policy and Company Performance}

One mechanism suggested by Jensen and Meckling (1976) was addition of debt portion. Addition of debt will reduce agency problems. Because the bigger the company debt, the smaller idle funds would be, which could be used for less necessary expenses. If debt was high, the company would have to reserve more cash for debt interest and also for installment of the principal debt. A high debt composition would reduce the company ability to pay out dividend to stock holders. An increase of debt would eventually impact the net profit for payout to stock holders (Oemar, 2014). 
Jensen dan Meckling (1976) stated that the utilization of debt in capital structure could prevent the company from spending money for unnecessary things and therefore would push the manager to manage the company more efficiently. This would reduce the agency cost and the performance of the company could be expected to improve. The utilization of debt in high portion in capital structure could possibly affect the manager's behavior. If everything was running well, the manager would use cash flow for bonus and other expenses not included in the agency cost. But a threat of bankruptcy due to debt could reduce unnecessary expenses, hence would increase free cash flow.

Brigham and Houston (2013) stated that profitability was a net result of a series of policies and decisions. Profitability Ratio was a ratio between the company profit and investment or equity used to gain the profit. Myers (1984) suggested that manager should use pecking order for funding decision. Pecking order was a priority level to use fund for investment i.e profit was retained as first option, followed by debt and equity. If this was correct, there would be the implication of a negative relation between company profitability and debt ratio. The internal party (insiders) did not wish to share profit with the creditor, as a consequence, debt ratio of the company tend to be smaller.

Further research found out Pecking Order theory was not applicable to all situation. In a case when the sum of debt ratio was relatively low, the higher the debt ratio, the higher ROE would be. There was a boundary point or cut-off where in certain level, the theory of Pecking Order was not applicable. Whenever company debt ratio had not reached the cut-off, every increase of debt ratio (DER) would also increase profit (ROE). Determination of cut-off or boundary point was conducted through two phases, firstly by determining square equation and secondly determining the maximum point by means of first derivation pecking order, i.e the higher the debt ratio, the lower the profit ratio (Wahyudi, 2004). Basically, the higher Return On Assets (ROA), the lower debt to be used for funding activities would be.

The relation between debt policy and company performance was based on research by Sheisarvian et.al (2015) which showed that company performance measured from profitability gave a negative and significant impact on company debt. Maftukhah (2013) in her research showed that ROA performance gave a negative and significant impact on DER. In a low level of profitability, company would use debt to fund operational activities. On the other hand when the level of profitability was high, the company would reduce debt usage. This was because the company would allocate greater part of the profit to retained profit so the company could count on internal sources, hence, the debt would be low. A company with high profitability would have abundant fund on hand for investment, and this would reduce the use of fund through of debt. In case of low profitability, the company was forced to have a high debt as a resource transfer mechanism from the creditors to the principal. On the other hand, the relation between debt policy and company performance was also based on Hamidah (2013) research in which Debt to total asset ratio gave a negative and significant impact on profitability (ROA) of banking companies listed at the Indonesian Stock Exchange, and Omar (2014) whose research showed that debt equity ratio gave on negative but insignificant impact on profitability performance.

H1e : There was a mutual relation between debt policy and company performance on manufacturing companies listed at the Indonesian Stock Exchange.

\section{Mutual Relation between Dividend Policy and Company Performance}

Agency theory is a theory explaining agency relationship and the problems generated (Jensen and Meckling, 1976). Agency relationship was a relation between two parties, in which the first party act as principal, and the second party (agent) acting as intermediary, representing principal to do transaction with third parties. Dividend policy, basically, determined the portion of profit to be paid out to stock holders, and to be retained for reinvestment into the company as a retained profit. The high portion of debt would cause a low capacity of the company to pay out dividend to stock holders, making the 
dividend pay out ratio low. From the above analysis, it could be concluded that the higher the dividend payout ratio, the better to company performance, Oemar (2014).

Joher et al. (2006) stated that the dividend policy was an indicator whether a company would have a better performance in the future. In this case, agency performance or manager were reliable, responsible and gave benefit to principal or investors. Joher's research proved that dividend policy had a positive and insignificant relation with company performance. Research by Shahab-u-Din and Javid (2011) showed that dividend policy had a positive and significant relation with company performance. This was due to the fact that the increase of dividend payout level would show that the company was using leverage to fund investment since the internal case flow had been used for dividend payout.

Modigliani \& Miller in Nuringsih (2005) stated that a dividend increase was a sign to investor that the company management predicted a prosperous profit in the future. On the other hand, a decline in dividend was believed by investors that the company would encounter tough times in the time to come. This would mean that the company capacity to pay out profit was increased due to better performance of the company. Beside that, if the company increase dividend payout, the investors would see it as a sign of management hope for better company performance in the future, thus dividend policy gave an impact on company value.

The relation between dividend policy and company performance was based on research by Oemar (2014) which showed that dividend payout ratio gave a negative and significant impact on profitability performance. Vise versa relation was proved by researchers of Kardianah (2013); Purwoko (2013); Thaib and Taroreh (2015); and Ranette and Wahasari (2013), which proved that profitability as an indicator of management work to manage company wealth gave a positive and significant impact on dividend policy. Whereas research by Dharmastuti (2013) showed that profitability did not affect dividend policy, and it had a negative coefficient.

Hif : There was a mutual relation between dividend policy and company performance on manufacturing companies listed at the Indonesian Stock Exchange.

\section{The impact of Institutional Ownership on Company Performance.}

According to Faizal (2004), a company with high institutional ownership indicated their ability to monitor the management of the company. The bigger the institutional ownership, the more efficient the utilization of company assets; hopefully this can function as a prevention towards management dissipation. Further, control function of owner was very crucial for improving company performance. Supervision to the company would increase in line with the high institutional ownership and if management could act according to the stock holders wish, the financial performance of the company would improve (Darwis, 2009). Eriandani (2013) also stated that institutional ownership was one factor that could affect company performance.

Institutional ownership was one way which could be done to reduce agency conflicts between agent and principal, because a big institutional ownership was considered capable as supervising mechanism for every decision made by the manager. So a high institutional ownership could reveal manager capability to utilize company asset. Therefore manager would be very careful in making company decision and this would push the manager to increase the company performance. Research by Hermiyetti and Katlanis(2014) revealed that institutional ownership gave a positive impact on company performance on manufacturing companies listed at Indonesian Stock Exchange.

$\mathrm{H} 2 \mathrm{a}$ : Institutional ownership gave a positive impact on company performance on manufacturing companies listed at the Indonesian stock Exchange.

\section{The Impact of Debt Policy on Company Performance}


A company financial performance could be valued from how the company manage debt to fund activities of the company. Myers and Majluf in Gunawan and Astuti (2015) stated Pecking order theory which described a hierarchy in looking for company funds where the company preferred to use internal equity to pay out dividend, implemented it as the development opportunities. Whenever internal funding was inadequate, the company would decide for external funding from debt, with this debt the company would have to pay interest which would consenquently reduce tax. With smaller tax, the net income would be bigger and this would affect company financial performance.

The relation between debt and company performance was based on research by Hamidah (2013) in which debt to total assets ratio gave a negative and significant impact on profitability (ROA) on banking companies listed at Indonesian Stock Exchange, and Oemar (2014) in his research said that Debt Equity Ratio gave negative but insignificant impact on profitability performance.

$\mathrm{H} 2 \mathrm{~b}$ : Debt policy had a negative impact on manufacturing companies listed at the Indonesian Stock Exchange.

9. The Impact of Dividend Policy on Company Performance.

Dividend was profit distribution of a company to stock holders in proportion with stocks owned (Baridwan, 2004). Decision about dividend payout was the company's decision as to how much profit would the stock holders on investors be entitled, (Brigham dan Houston, 2006). Dividend would affect the stock holders assets (Adesola and Okwong, 2009). The bigger the company profit, the bigger dividend proportion would be. Profit rate was the level of assets return expected to relatively determine to pay out dividend to stock holders (who would spend the money somewhere else), or to use the money within the company. A company with stable profit could frequently predict how much profit they would gain in the future.

Sukendro and Pujiharjanto (2012) found out that company policy of not paying out dividend would affect the company performance. The relation between dividend policy and company performance based on research by Oemar (2014) showed that dividend payout ratio had a negative and significant. Impact on profitability performance.

$\mathrm{H} 2 \mathrm{c}$ : dividend policy had a positive impact on manufacturing companies listed at the Indonesian Stock Exchange.

\section{Research Framework}

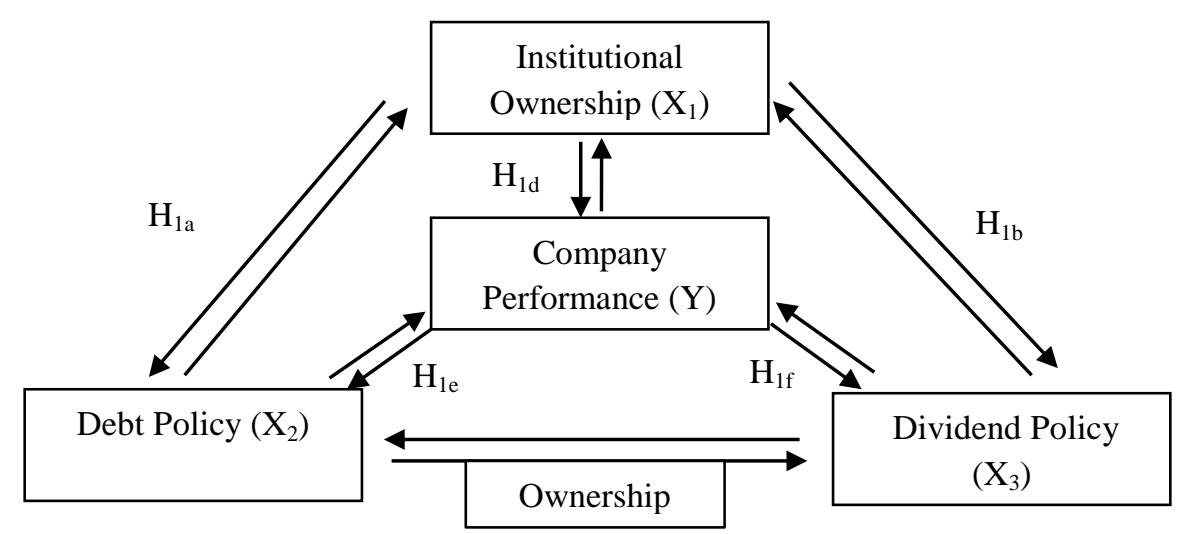

Picture 1

Conceptual Framework of Mutual Relation Among Variables

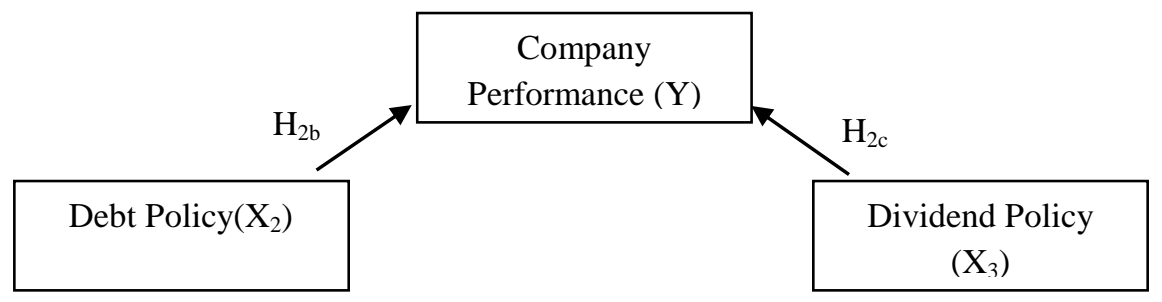

Picture 2

Conceptual Framework of Inter Variables Impact 


\section{Hypothesis of The Research}

Hypothesis in this research were :

$\mathrm{H}_{1 \mathrm{a}}$ : There was a mutual relation between institutional ownership and debt policy in manufacturing company listed at the Indonesian stock exchange.

$\mathrm{H}_{1 \mathrm{~b}}$ : There was a mutual relation between institutional ownership and dividend policy in manufacturing companies listed at the Indonesian Stock Exchange.

$\mathrm{H}_{1 \mathrm{c}}$ : There was a mutual relation between debt policy and dividend policy on manufacturing companies listed at the Indonesian Stock Exchange.

$\mathrm{H}_{1 \mathrm{~d}}$ : There was a mutual relation between institutional ownership and company performance on manufacturing companies listed at the Indonesian Stock Exchange.

$\mathrm{H}_{1 \mathrm{e}}$ : There was a mutual relation between debt policy and company performance on manufacturing company listed at Indonesian stock Exchange.

$\mathrm{H}_{\mathrm{if}}$ : There was a mutual relation between dividend policy and company performance on manufacturing company listed at the Indonesian stock Exchange.

$\mathrm{H}_{2 \mathrm{a}}$ : Institutional ownership gave a positive impact on company performance on manufacturing companies listed at the Indonesian stock Exchange.

$\mathrm{H}_{2 \mathrm{~b}}$ : Debt policy gave a negative impact on manufacturing companies listed at the Indonesian Stock Exchange.

$\mathrm{H}_{2 \mathrm{c}}$ : Dividend policy gave a positive impact on manufacturing companies listed at the Indonesian Stock Exchange.

\section{Population And Sampling}

Population was a generalization consisting of objects or subjects having certain characteristics and quality determined by a research to be studied and drawing conclusion (Sugiyono, 2007). Population in this research were manufacturing companies listed at the Indonesia Stock Exchange.

Research sampling in this study were manufacturing companies listed at Indonesian Stock Exchange within the period of 2006-2015. Sampling techniques was purposive sampling, a technique of sampling with certain consideration i.e subjects selection based on the criteria as follows :

a. The companies had a complete financial reports within the period of research, 2006-2015.

b. The availability of complete financial data for research variables, within the period of research.

c. Companies used the Indonesian (rupiah) currency in their financial reports.

d. Companies reported institutional ownership (institutional stock holders). This point was significant to equip research data to avoid zero (0).

e. Companies had managerial ownership. This was significant to equip research data to avoid zero (0). 
Table 1.

Research Sample Criteria

\begin{tabular}{|c|l|c|}
\hline No. & \multicolumn{1}{|c|}{ Explanation } & $\begin{array}{c}\text { The number of } \\
\text { companies }\end{array}$ \\
\hline 1 & $\begin{array}{l}\text { The number of manufacturing companies at the } \\
\text { Indonesian Stock Exchange within 2015 }\end{array}$ & 141 \\
\hline 2 & $\begin{array}{l}\text { Companies did not have complete financial report } \\
\text { during the period of research, 2016-2015. }\end{array}$ & 41 \\
\hline 3 & $\begin{array}{l}\text { Companies did not submit report of institutional } \\
\text { ownership (Institutional stock holders) }\end{array}$ & 2 \\
\hline Number of companies taken as samples & 98 \\
\hline \multicolumn{2}{|c|}{ Number of observation (48 x 10) } & 480 \\
\hline
\end{tabular}

\section{Research Variables and Operational Variables Definition}

\section{Research Variable :}

Independent variables in this research were

1) Institutional Ownership (X1)

Institutional ownership was symbolized (INST), stocks proportion in percentage, owned by the institution at the end of the year. This variable described the level of stock owned by the institution in a

company. Institutional ownership in this research was measured through stock owned by the institution divided by total stock outstanding with a formula referring to Inanta and Satwiko (2011) :

$$
I N S T=\frac{\text { Institutional Stocks }}{\text { Total Stocks Outstanding }}
$$

2) Debt Policy (X2)

Debt Policy was capital fund of a company where the proportion of debt used was bigger than the company owned capital. (Brigham and Huston, 2001). Debt policy in this research was measured from Debt to Equity, i.e total debt divided by total equity (DER), using formula referring to Sartono (2000) as follows :

$$
D E R=\frac{\text { Total Debt }}{\text { equity }}
$$

3) Dividend Policy $\left(\mathrm{X}_{3}\right)$

Dividend Policy was a policy or decision whether the company gained profit could be paid out to stock holders as dividend or kept as retained profit for future investment (Sartono, 2000). Dividend policy in this research was measured by Dividend Payout Ratio (cash dividend) divided by net income (DPR) with a formula referring to Murhadi (2013), as follows:

$$
D P R=\frac{\text { Dividend Per Share }}{\text { Earning Per Share }}
$$

4) Company Performance $\left(\mathrm{X}_{4}\right)$

Company Performance was an assessment or interpretation of company financial condition by an analyst through financial data. Company performance in this research was measured through Return 
on Equity (ROE). ROE was chosen because this ratio revealed parts of the profit originated from own capital which was frequently utilized by investors to buy company stocks (Rahardjo, 2005: 122). Return on Equity (ROE) was calculated by using the following formula (Syamsuddin, 2009:65):

\section{Data Analysis}

$$
R O E=\frac{\text { Net Profit After Tax }}{\text { Stockholder Equity }}
$$

In this study, the researcher used quantitative analysis technique, with the following steps:

1. Based on prior studies and researches, research problems were formulated and the aim of the research was determined.

2. Framework was illustrated.

3. Granger causality test was conducted to find out the relation of researched variables. Granger Causality test was one method of analysis explaining whether a variable had vice versa relation or only one way relation. Basically, granger test was to see the effect in the past to the present condition so data used are time series data. Granger Causality could show:

a. Causality was a mutual relation with Granger method between Institutional Ownership variable = KI $\left(\mathrm{X}_{1}\right)$ and Debt Policy $=\operatorname{DER}\left(\mathrm{X}_{2}\right)$, formulated as follows:

$$
\begin{aligned}
K I_{t} & =\sum_{i=l}^{m} \alpha_{i} K I_{t-i}+\sum_{j=l}^{m} \beta_{j} D E R_{t-j}+U_{1 t} \\
D E R_{t} & =\sum_{i=l}^{m} \lambda_{i} D E R_{t-i}+\sum_{j=l}^{m} \delta_{j} K I_{t-j}+U_{2 t}
\end{aligned}
$$

$\mathrm{KI}=$ Institutional Ownership

DER $=$ Debt

$\mathrm{Ut} \quad=\quad$ Confounding Variable

$\mathrm{m}=\quad$ The number of lag

b. The relation between Institutional Ownership variable $=\mathrm{KI}\left(\mathrm{X}_{1}\right)$ with Divident Policy $=\mathrm{DPR}\left(\mathrm{X}_{3}\right)$, formulated as follows: $K I_{t}=\sum_{i=l}^{m} \propto_{i} K I_{t-i}+\sum_{j=l}^{m} \beta_{j} D P R_{t-j}+U_{1 t}$

$$
D P R_{t}=\sum_{i=l}^{m} \lambda_{i} D P R_{t-i}+\sum_{j=l}^{m} \delta_{j} K I_{t-j}+U_{2 t}
$$

$\mathrm{KI}=$ Institutional Ownership

$\mathrm{DPR}=$ Dividend

$\mathrm{Ut}=$ Confounding Variable

$\mathrm{m}=\quad$ The number of lag

c. The relation between Debt Policy variable $=$ DER $\left(\mathrm{X}_{2}\right)$ with Dividend Policy $=\mathrm{DPR}\left(\mathrm{X}_{3}\right)$, formulated as follows:

$$
\begin{aligned}
& D E R_{t}=\sum_{i=l}^{m} \propto_{i} D E R_{t-i}+\sum_{j=l}^{m} \beta_{j} D P R_{t-j}+U_{1 t} \\
& D P R_{t}=\sum_{i=l}^{m} \lambda_{i} D P R_{t-i}+\sum_{j=l}^{m} \delta_{j} D E R_{t-j}+U_{2 t}
\end{aligned}
$$
DER $=$ Debt
$\mathrm{DPR}=$ Dividend
$\mathrm{Ut}=$ Confounding Variable 
$\mathrm{m} \quad=\quad$ The number of lag

d. The relation between Institutional Ownership $=\mathrm{KI}\left(\mathrm{X}_{1}\right)$ and Company Performance $=\mathrm{ROE}\left(\mathrm{X}_{4}\right)$, formulated as follows:

$$
\begin{aligned}
K I_{t} & =\sum_{i=l}^{m} \alpha_{i} K I_{t-i}+\sum_{j=l}^{m} \beta_{j} R O E_{t-j}+U_{1 t} \\
R O E_{t} & =\sum_{i=l}^{m} \lambda_{i} R O E_{t-i}+\sum_{j=l}^{m} \delta_{j} K I_{t-j}+U_{2 t}
\end{aligned}
$$

$\mathrm{KI}=$ Institutional Ownership

$\mathrm{ROE}=$ Company Performance

$\mathrm{Ut}=$ Confounding Variable

$\mathrm{m}=\quad$ The number of lag

e. The relation between Debt Policy variable $=\operatorname{DER}\left(\mathrm{X}_{2}\right)$ and Company Performance $=\mathrm{ROE}\left(\mathrm{X}_{4}\right)$, formulated as follows:

$$
\begin{aligned}
D E R_{t} & =\sum_{i=l}^{m} \alpha_{i} D E R_{t-i}+\sum_{j=l}^{m} \beta_{j} R O E_{t-j}+U_{1 t} \\
R O E_{t} & =\sum_{i=l}^{m} \lambda_{i} R O E_{t-i}+\sum_{j=l}^{m} \delta_{j} D E R_{t-j}+U_{2 t}
\end{aligned}
$$
DER $=$ Debt Policy
$\mathrm{ROE}=$ Company Performance
$\mathrm{Ut}=$ Confounding Variable
$\mathrm{m}=$ The number of lag

f. The relation between Dividend Policy variable $=\operatorname{DPR}\left(\mathrm{X}_{3}\right)$ and Company Performance $=\mathrm{ROE}\left(\mathrm{X}_{4}\right)$, formulated as follows:

$$
\begin{aligned}
D P R_{t} & =\sum_{i=l}^{m} \alpha_{i} D P R_{t-i}+\sum_{j=l}^{m} \beta_{j} R O E_{t-j}+U_{1 t} \\
R O E_{t} & =\sum_{i=l}^{m} \lambda_{i} R O E_{t-i}+\sum_{j=l}^{m} \delta_{j} D P R_{t-j}+U_{2 t}
\end{aligned}
$$

$\begin{array}{lll}\text { DPR } & = & \text { Dividend Policy } \\ \text { ROE } & = & \text { Company Performance } \\ \mathrm{Ut} & = & \text { Confounding Variable } \\ \mathrm{m} & = & \text { The number of lag }\end{array}$

4. Based on granger causality test, the variable which significantly affected other variables would be revealed. Next panel regression test was conducted with multiple linear regression OLS.

5. Panel regression test which calculated direct dimension to find out a long term impact of independent variable on dependent variable. Data processing was facilitated with E-Views software.

6. Interpreting data processing, making conclusion and giving suggestion. Test was done by reviewing research model as follows:

$\mathrm{ROE}=\alpha+\beta_{1} \mathrm{INST}+\beta_{2} \mathrm{DER}+\beta_{3} \mathrm{DPR}+e$ 


\section{Granger Causality Test}

Granger Causality test showed F-statistical probability value $<\alpha=10 \%, 5 \%, 1 \%$, so there was a mutual relation. Otherwise if F-statistical probability $>\alpha=10 \%, 5 \%, 1 \%$ there was no mutual relation. Data analysis result using granger causality test was shown in table 4.3.

Table 2

\section{Granger Causality Test Result}

\begin{tabular}{lccc}
\hline \hline Null Hypothesis: & Obs & F-Statistic & Prob. \\
\hline \hline DPR does not Granger Cause DER & 784 & 0.39566 & 0.6734 \\
DER does nof Granger Cause DPR & & 0.47041 & 0.6249 \\
\hline \hline INST does not Granger Cause DER & 784 & 0.36914 & 0.6914 \\
DER does not Granger Cause INST & & 0.05118 & 0.9501 \\
\hline \hline ROE does not Granger Cause DER & 784 & 0.64621 & 0.5243 \\
DER does not Granger Cause ROE & & 0.34007 & 0.7118 \\
\hline \hline INST does not Granger Cause DPR & 784 & 0.88263 & 0.4141 \\
DPR does not Granger Cause INST & & 0.23100 & 0.7938 \\
\hline \hline ROE does not Granger Cause DPR & 784 & 2.21642 & 0.1097 \\
DPR does not Granger Cause ROE & & 7.56200 & 0.0006 \\
\hline \hline ROE does not Granger Cause INST & 784 & 0.50766 & 0.6021 \\
INST does not Granger Cause ROE & & 0.68681 & 0.5035 \\
\hline \hline
\end{tabular}

\section{Mutual Relation between Institutional Ownership and Debt Policy}

From GRANGER test in table 2, it could be concluded that Institutional Ownership (KI) did not relate to Debt Policy (DER), as seen based on significance value (Sig) of 0.6914. This showed that significance value was bigger than error rate (0.05). So was the case with the relation between Debt Policy (DER) and Institutional Ownership (KI), where there was no relation as shown by significance value (Sig) of 0.9501. Based on significance value to find out mutual relation between Institutional Ownership and Debt Policy of manufacturing companies listed at the Indonesian Stock Exchange, it could be concluded that there was no mutual relation between Institutional Ownership and Debt Policy.

\section{Mutual Relation between Institutional Ownership and Dividend Policy}

GRANGER test result in table 2 concluded that Institutional Ownership (KI) had no relation with Dividend Policy and vice versa. This was shown by significance values (Sig) of 0.4141 and 0.7938 . This indicated that significance value was bigger than error rate (0.05). This signified that Institutional Ownership (KI) had no significant relation with Dividend Policy and vice versa at $95 \%$ level of confidence. Based on significance value to see mutual relation between Institutional Ownership and Dividend Policy on manufacturing companies listed at the Indonesian Stock Exchange, it could be concluded that there was no mutual relation between Institutional Ownership and Dividend Policy.

\section{Mutual Relation between Debt Policy and Dividend Policy}

Debt Policy (DER) and Dividend Policy (DPR) in table 2 did not show significant relation and so did it otherwise. This was shown by significance values (Sig) of 0.6249 and 0.6734 . It indicated that significance value was bigger than error rate (0.05). This signified that Debt Policy (DER) had no significant relation with Dividend Policy and vice versa at $95 \%$ level of confidence. Based on significance value to see mutual relation between Debt Policy and Dividend Policy on manufacturing companies listed at the Indonesian Stock Exchange, it could be concluded that there was no mutual relation between Debt Policy and Dividend Policy.

\section{Mutual Relation between Institutional Ownership and Company Performance}


Table 2 showed that there was no relation between Institutional Ownership (KI) and Company Performance (ROE). This was shown by significance value (Sig) of 0.5035 . It indicated that the significance value was bigger than error rate (0.05). This signified that Institutional Ownership (KI) had no significant relation with Company Performance (ROE) at $95 \%$ confidence rate. So was it otherwise, Company Performance (ROE) had no relation with Institutional Ownership (KI). This was shown by significance value (Sig) of 0.6021. It indicated that significance value was bigger than error rate (0.05). This signified that Company Performance had no significant relation with Institutional Ownership at $95 \%$ level of confidence. Based on significance value to see mutual relation between Institutional Ownership and Company Performance on manufacturing companies listed at the Indonesian Stock Exchange, it could be concluded that there was no mutual relation between Institutional Ownership and Company Performance.

\section{Mutual Relation between Debt Policy and Company Performance}

Debt Policy (DER) and Company Performance (ROE) in table 2 did not show any relation and so was the case otherwise. This was shown by significance values (Sig) of 0.7118 dan 0.5243 . It indicated that significance value was bigger than error rate (0.05). This signified that Debt Policy (DER) had no significant relation with Company Performance at $95 \%$ level of confidence. Based on significance value to see mutual relation between Debt Policy and Company Performance on manufacturing companies listed at the Indonesian Stock Exchange, it could be concluded that there was no mutual relation between Debt Policy and Company Performance.

\section{Mutual Relation between Dividend Policy and Company Performance}

Table 2 showed that there was a significant relation between Dividend Policy (DPR) and Company Performance (ROE). This could be seen from significance value (Sig) of 0.0006. It indicated that significance value was bigger than error rate (0.05). This signified that Dividend Policy (DPR) had a significant relation with Company Performance (ROE) at $95 \%$ level of confidence. However, Company Performance (ROE) had no relation with Dividend Policy (DPR) as shown by significance value (Sig) of 0.1097. It indicated that significance value was bigger than error rate (0.05). This signified that Company Performance had a significant relation with Dividend Policy at $95 \%$ level of confidence. Based on significance value to see mutual relation between Dividend Policy and Company Performance on manufacturing companies listed at the Indonesian Stock Exchange, it could be concluded that there was a relation between Dividend Policy and Company Performance but there was no relation between Company Performance and Dividend Policy.

\section{Table 3}

\section{Impact Test Result of INST, DER, DPR on ROE}

\begin{tabular}{|c|c|c|c|c|c|}
\hline & Variable & Coefficient & Std. Error & t-Statistic & Prob. \\
\hline \multirow{4}{*}{$\begin{array}{c}\text { Constants } \\
\text { Institutional Ownership } \\
\text { Debt Policy } \\
\text { Dividend Policy }\end{array}$} & onstants & -0.001234 & 0.068945 & -0.017896 & 0.9857 \\
\hline & can Institusional & 0.237803 & 0.093626 & 2.539917 & 0.0112 \\
\hline & ıkan Hutang & -0.055893 & 0.001790 & -31.21917 & 0.0000 \\
\hline & kkan Dividen & 0.188396 & 0.060284 & 3.125117 & 0.0018 \\
\hline \multicolumn{2}{|c|}{ R-squared } & \multicolumn{3}{|c|}{0.505363 Mean dependent var } & 0.095638 \\
\hline \multicolumn{2}{|c|}{ Adjusted R-squared } & \multicolumn{3}{|c|}{0.503843 S.D. dependent var } & 0.739566 \\
\hline \multicolumn{2}{|c|}{ S.E. of regression } & \multicolumn{3}{|c|}{0.520939 Akaike info criterion } & 1.537705 \\
\hline \multicolumn{2}{|c|}{ Sum squared resid } & \multicolumn{3}{|c|}{ 264.8641 Schwarz criterion } & 1.557654 \\
\hline \multicolumn{2}{|c|}{ Log likelihood } & \multicolumn{3}{|c|}{-749.4753 Hannan-Quinn criter. } & 1.545294 \\
\hline \multicolumn{2}{|c|}{ F-statistic } & \multicolumn{3}{|c|}{ 332.3880 Durbin-Watson stat } & 2.155442 \\
\hline & Prob(F-statistic) & \multicolumn{3}{|c|}{0.000000} & \\
\hline
\end{tabular}

ROE $=-0.0012+0.237$ INST -0.056 DER +0.188 DPR 


\section{Institutional Ownership (INST) towards Company Performance (ROE)}

The impact of Institutional Ownership (INST) towards Company Performance (ROE) as shown in table 4.4 had a significance value (Sig) of 0.0012 which was smaller than error rate (0.05). Therefore it could be concluded that Institutional Ownership (INST) had a significant impact on Company Performance (ROE). The value of beta positive showed that Institutional Ownership (INST) had a positive impact of 0.23 on Company Performance (ROE).

\section{Debt Policy (DER) towards Company Performance (ROE)}

The impact of Debt Policy (DER) towards Company Performance (ROE) as shown in table 4.4 had a significance value (Sig) of 0.0000 which was smaller than error rate (0.05). Thus it could be concluded that Debt Policy (DER) had a significant impact on Company Performance (ROE). The value of beta negative showed that Debt Policy (DER) had a potential impact to reduce Company Performance (ROE) with beta value of -0.0055 .

\section{Dividend Policy (DPR) towards Company Performance (ROE)}

Dividend Policy (DPR) had a significant impact on Company Performance with a significance value (Sig) of 0.0018 , smaller than error rate (0.05). Both variables showed positive impact with beta value of 0.188396, which meant that if Dividend Policy (DPR) was increased by one point, ROE would increase by 0.188396, with the assumption the Institutional Ownership (INST) and Debt Policy (DER) variables were constant.

Partial impact of independent variable on dependent variable is briefly presented on the following table.

\section{Table 4}

\section{Partial Period Test of INST, DER, DPR Towards ROE}

\begin{tabular}{crrrr}
\hline \hline Variable & Coefficient & Std. Error & t-Statistic & Prob. \\
\hline Constant & -0.041717 & 0.063821 & -0.653656 & 0.5135 \\
ROE(-1) & 0.049673 & 0.028249 & 1.758435 & 0.0791 \\
ROE(-2) & 0.142636 & 0.019100 & 7.467783 & 0.0000 \\
DER & -0.066306 & 0.001668 & -39.75678 & 0.0000 \\
DER(-1) & 0.021822 & 0.002352 & 9.276957 & 0.0000 \\
DPR & 0.093305 & 0.058690 & 1.589805 & 0.1123 \\
DPR(-1) & 0.218616 & 0.058986 & 3.706231 & 0.0002 \\
INST & -0.112992 & 0.208125 & -0.542908 & 0.5873 \\
INST(-1) & 0.309110 & 0.205331 & 1.505423 & 0.1326 \\
\hline \hline R-squared & 0.689300 Mean dependent var & 0.073098 \\
Adjusted R-squared & 0.686093 & S.D. dependent var & 0.739447 \\
S.E. of regression & 0.414293 & Akaike info criterion & 1.086926 \\
Sum squared resid & 133.0200 Schwarz criterion & 1.140472 \\
Log likelihood & -417.0751 Hannan-Quinn criter. & 1.107516 \\
F-statistic & 214.9214 & Durbin-Watson stat & 2.286796 \\
Prob(F-statistic) & 0.000000 & & & \\
\hline \hline
\end{tabular}

$\mathrm{ROE}=-0.042+0.049 * \mathrm{ROE}(\mathrm{t}-1)+0.143 * \mathrm{ROE}(\mathrm{t}-2)-0.066 * \mathrm{DER}+0.022 * \mathrm{DER}(\mathrm{t}-1)+0.093 * \mathrm{DPR}+$ $0.219 * \operatorname{DPR}(\mathrm{t}-1)-0.113 * \operatorname{INST}+0.309 * \operatorname{INST}(\mathrm{t}-1)$

F-statistical value $=214.92$, bigger than $\mathrm{F}_{\text {tabel }}=\mathrm{F}_{8,970,0.05}=1.677$, or Prob(F-statistic $)=0.000$ smaller than $\alpha=0,05$ meaning Ho rejected, therefore there was a significant impact of variables $\mathrm{ROE}(\mathrm{t}-1), \operatorname{ROE}(\mathrm{t}-2)$, $\operatorname{DER}(\mathrm{t}), \operatorname{DER}(\mathrm{t}-1), \operatorname{DPR}(\mathrm{t}), \operatorname{DPR}(\mathrm{t}-1), \operatorname{INST}(\mathrm{t}), \operatorname{INST}(\mathrm{t}-1)$ towards $\operatorname{ROE}(\mathrm{t})$ variable.

Table 4 showed Prob value smaller than 0.05 and 0.10 of ROE(t-1), ROE(t-2), DER(t), DER(t-1), $\operatorname{DPR}(t), \operatorname{DPR}(\mathrm{t}-1), \operatorname{INST}(\mathrm{t}), \operatorname{INST}(\mathrm{t}-1)$, which meant that those variables partially affect ROE. This meant that $\operatorname{ROE}(\mathrm{t}-1), \operatorname{ROE}(\mathrm{t}-2), \operatorname{DER}(\mathrm{t}), \operatorname{DER}(\mathrm{t}-1), \operatorname{DPR}(\mathrm{t}), \operatorname{DPR}(\mathrm{t}-1), \operatorname{INST}(\mathrm{t}), \operatorname{INST}(\mathrm{t}-1)$ had a significant impact on ROE. 


\section{Conclusion}

1. Institutional Ownership does not have significant relation with Debt Policy. Similarly, the relation between Debt Policy and Institutional Ownership is insignificant. Thus, there is no mutual relation between Institutional Ownership and Debt Policy on manufacturing companies at the Indonesian Stock Exchange.

2. Institutional Ownership does not have significant relation with Dividend Policy. Vice versa, Dividend Policy does not have significant relation with Institutional Ownership. Therefore, there is no mutual relation between Institutional Ownership and Dividend Policy on manufacturing companies at the Indonesian Stock Exchange.

3. Debt Policy does not have significant relation with Dividend Policy. Similarly, Dividend Policy does not have significant relation with Debt Policy. Therefore, there is no mutual relation between Debt Policy and Dividend Policy on manufacturing companies at the Indonesian Stock Exchange.

4. Institutional Ownership does not have significant relation with Company Performance. Vice versa, Company Performance does not have significant relation with Institutional Ownership. Therefore, there is no mutual relation between Institutional Ownership and Company Performance on manufacturing companies at the Indonesian Stock Exchange.

5. Debt Policy is not related to Company Performance. Vice versa, Company Performance is not related to Debt Policy. Therefore, there is no mutual relation between Debt Policy and Company Performance on manufacturing companies at the Indonesian Stock Exchange.

6. Dividend Policy has significant relation with Company Performance, but Company Performance does not have relation with Dividend Policy. Thus, it can be concluded that there is no mutual relation between Dividend Policy and Company Performance on manufacturing companies at the Indonesian Stock Exchange.

7. Institutional Ownership has a partial positive and significant impact on Company Performance on manufacturing companies listed at the Indonesian Stock Exchange.

8. Debt Policy has a partial positive and significant impact on Company Performance on manufacturing companies listed at the Indonesian Stock Exchange.

9. Dividend Policy has a partial positive and significant impact on Company Performance on manufacturing companies listed at the Indonesian Stock Exchange.

\section{References}

[1] Adesola, W. A. and A. E. Okwong. 2009. An Emparical Study of Dividend Policy of Quoted Companies in Nigeria. Global Journal of Social Sciences. 8 (1):85-101

[2] Al-Najjar, B. and Hussainey, K. 2009. The association between dividend payout and outside Directorships, Journal of Applied Accounting Research, Vol. 10, pp. 4-19

[3] Baridwan, Z. 2004. Intermediate Accounting. Edisi Kedelapan. Cetakan. Pertama. Yogyakarta: BPFE.

[4] Beiner, S., Drobetz, W., et al, 2003, Is Board size an Independent Corporate Governance Mechanism, www.ssrn.com (diakses tanggal 29 Januari 2008).

[5] Brigham, Eugene F and Joel F.Houston, 2006. Dasar-Dasar Manajemen Keuangan, alih bahasa Ali Akbar Yulianto, Buku satu, Edisi sepuluh, PT. Salemba Empat, Jakarta.

[6] Chen, R. Carl dan Steiner, T. 1999. "Managerial Ownership and Agency Conflicts: A Nonlinear Simultaneous Equation Analysis of Managerial Ownership, Risk Taking, Debt Policy, and Dividend Policy", Financial Review, Vol.34.

[7] Crutchley dan Hansen. 1989. A Test of Agency Theory of Managerial Ownership. Corporate Leverage And Corporate Dividends. Financial Management. Vol 18. No. 4. Pp. 36-46. 
[8] Crutchley et al. 1999. Agency Problems and the Simultaneity of Financial Decision. Making The role of institutional ownership. International Review of Financial Analysis 8. Hal. 177-197.

[9] Darwis, H. 2009. " Corporate Governance Terhadap Kinerja Perusahaan”,. Jurnal Keuangan dan Perbankan, Vol.13, No 13. Hal. 418-430

[10] Dharmastuti, C. F. 2013. Analisis Pengaruh Mekanisme Internal dan External Corporate Governance Terhadap Profitabilitas dan Kebijakan Dividen Perusahaan. Jurnal Organisasi dan Manajemen, Vol. 9. No. 1. pp. 21-30.

[11] Easterbrook, F.H. 1984. "Two Agency-Cost Explanations of Dividends," American Economic Review. Vol. 74, hal. 650-659.

[12] Eriandani, R. 2013. "Pengaruh Institutional Ownership dan Managerial Ownership terhadap Pengungkapan CSR pada Laporan Tahunan Perusahaan Studi Empiris pada Perusahaan Manufaktur 2010-2011" Simposium Nasional Akuntansi XVI

[13] Gautama, B., P., \& Haryati, Y. 2014. Pengaruh Struktur Kepemilikan dan Kebijakan Hutang Terhadap Kebijakan Dividen Pada Subsektor Konstruksi dan Bangunan Yang Tercatat di BEI'. IMAGE, Volume III Nomor 2.

[14] Hermiyetti dan E. Katlanis. 2014. Analisis Pengaruh Kepemilikan Manajerial, Kepemilikan Institusional, kepemilikan asing, dan Komite Audit terhadap Kinerja Keuangan Perusahaan. Media Riset Akuntansi, Vol.6 No.2

[15] Jensen, M. C and Meckling, W.H. 1976. Theory of the Firm: Managerial Behavior, Agency Costs and Ownership Structure . Journal of Financial Economics, Oktober, 1976, V. 3, No. 4, pp. 305-360. Avalaible from: http://papers.ssrn.com.

[16] Joher, H., Ali, M., \& Nazrul. 2006. The Impact Of Ownership Structure On Corporate Debt Policy: Two Stage Least Square Simultaneous Model Approach For Post Crisis Period: Evidence From Kuala Lumpur Stock Exchange. International Business \& Economics Research Journal Volume 5, Number 5.

[17] Kardianah. 2013. Pengaruh Kepemilikan Institusional, Kebijakan Utang, Ukuran Perusahaan, Profitabilitas dan Likuiditas Terhadap Kebijakan Dividen. Jurnal Ilmu \& Riset Manajemen Vol. 2 No. 1.

[18] Karinaputri, Nanda. 2012. Analisa Pengaruh Kepemilikan Institusional, Kebijakan Dividen, Profitabilitas dan Pertumbuhan Perusahaan Terhadap Kebijakan Hutang (Studi Pada Perusahaan Manufaktur yang Terdaftar Di Bursa Efek Indonesia Tahun 2008-2010). Skripsi. Fakultas Ekonomi Dan Bisnis UNDIP Semarang.

[19] Larasati, Eva. 2011. Pengaruh Kepemilikan Manajerial, Kepemilikan Institusional, dan Kebijakan Dividen terhadap Kebijakan Hutang Perusahaan. Journal Ekonomi Bisnis, TH. 16, No.2.

[20] Maftukhah, I. 2013. Kepemilikan Manajerial, Kepemilikan Institusional, Dan Kinerja Keuangan Sebagai Penentu Struktur Modal Perusahaan. Jurnal Dinamika Manajemen Vol. 4, No. 1.

[21] Mardiasmo. 2004. Akuntansi Sektor Publik (Edisi Kedua). Yogyakarta: Andi.

[22] Megginson, W.L. 1997. Corporate Finance Theory. Addison-Wesley Educational Publishers Inc.

[23] Modigliani, \& Miller M.H, 1958,

[24] Nuringsih, Kartika. 2005. Analisis Pengaruh Kepemilikan Managerial, Kebijakan Hutang, ROA dan Ukuran Perusahaan terhadap Kebijakan Dividen: Studi 1995-1996. Jurnal Akuntansi dan Keuangan Indonesia, Vol. 2, No. 2, hlm.103 123.

[25] Oemar. F. 2014. Pengaruh Corporate Governance dan keputusan Pendanaan. Perusahaan Terhadap Kinerja Profitabilitas dan Implikasinya Terhadap. Harga Saham (Studi Empiris pada Perusahaan BUMN yang Listing di BEI tahun 2008-2011). Jurnal Ilmiah Ekonomi dan Bisnis Vol. 11 No.2, PP $27: 36$. 
[26] Porter, R. E., Jr., and P. S. Holt. 1992. Effect of induced molting on the severity of intestinal lesions caused by Salmonella enteritidis infection in chickens. Avian Dis. 37:1009-1016.

[27] Riyanto, B. 2001. Dasar-Dasar Pembelanjaan Perusahaan, Edisi. Keempat, Cetakan Ketujuh, BPFE Yogyakarta, Yogyakarta.

[28] Srimindarti, Ceacilia. 2004. Balanced Scorecard Sebagai Alternatiff Untuk Mengukur Kinerja. Fokus Ekonomi, Vol 3 No 1.

[29] Sukendro, J., dan C. A. Pujiharjanto. 2012. Pengaruh Kebijakan Dividen terhadap Kinerja Perusahaan di Indonesia (Studi Empirik pada Perusahaan-perusahaan Non Keuangan yang terdaftar di Bursa Efek Indonesia dengan Probabilistic Regresion Model). Proocedings Of Conference In Business, Accounting and Management (CBAM). Vol. 1 No. 1

[30] Syamsuddin, L. 2009. Manajemen Keuangan Perusahaan. Jakarta: PT. Raja Grafindo Persada.

[31] Tandelilin, Eduardus. 2010. Portofolio dan Investasi - Teori dan Aplikasi. Yogyakarta: Kanisius.

[32] Wati, K., M. 2012. Simultanitas Struktur Kepemilikan, Kebijakan Dividen dan hutang. JRAK, Volume 8, No.2.

[33] Van Horne, James C dan Wachowicz, John M Jr. 1997. Prinsip-prinsip Manajemen Keuangan. Alih Bahasa Heru Sutojo. Edisi Kesembilan. Salemba Empat. Jakarta.

[34] Wiranata, Y.A. dan Nugrahanti, Y.W. 2013. Pengaruh Struktur Kepemilikan terhadap Profitabilitas Perusahaan Manufaktur di Indonesia. Jurnal. Akuntansi dan Keuangan, Vol. 15, No. 1, Mei 2013, 15-26.

\section{Author Profile}

Mateus Xavier Da Costa Cabral currently is a Dr (cand.) in Postgraduate Schhool of Universitas Katolik Widya Mandala Surabaya and Lecturer at Universidade da Paz (UNPAZ) Timor Leste.

Prof.Dr. Arsono Laksana., Akt, is a lecturer at Postgraduate School of Universitas Katolik Widya Manda Surabaya.

Dr. Mudjilah Rahayu is a lecturer at Postgraduate School of Universitas Katolik Widya Mandala Surabaya. 